\title{
Optimalisasi Penggunaan Frekuensi dan Peningkatan Throughput pada Jaringan LTE-A menggunakan Metode CADS2
}

\author{
HASANAH PUTRI, MINAL ABI PUTRA \\ Program Studi D3 Teknologi Telekomunikasi Telkom University, Indonesia \\ Email : hasanahputri@tass.telkomuniversity.ac.id
}

Received 15 Juni 2020 | Revised 11 Juli 2020 | Accepted 28 Agustus 2020

\begin{abstract}
ABSTRAK
Penelitian kali ini mengamati data Operating Support System (OSS) operator untuk wilayah Ciparay Bandung. Berdasarkan data OSS, Ciparay memiliki penetrasi jaringan LTE-A sebesar 90\%, hal ini menunjukkan bahwa trafik di area tersebut sangat padat. Selain itu, nilai throughput jaringan LTE-A di area ini hanya sebesar 6.8 Mbps. Hal ini masih belum memenuhi standar operator dimana throughput $>$ 16 Mbps. Untuk mengatasi hal ini, dilakukan optimalisasi penggunaan frekuensi dan peningkatan throughput menggunakan metode Carrier Aggregation Deployment Scenario 2 (CADS2) dimana dilakukan penggabungan dua buah component carrier pada bandwidth $15 \mathrm{MHz}$ di band $3(1800 \mathrm{MHz}$ ) dan bandwidth 20 di band 40 (2300 MHz). Dimana pada skenario I, band 3 dijadikan primary cell dan band 40 dijadikan secondary cell. Sedangkan pada skenario II, band 40 dijadikan primay cell dan band 3 dijadikan secondary cell. Hasil yang diperoleh yaitu terjadi peningkatan rata-rata throughput sebesar $94,87 \%$.
\end{abstract}

Kata kunci: LTE-A, OSS operator, CADS2, throughput, Ciparay Bandung

\begin{abstract}
This research examines operator Operating Support System (OSS) data for the Ciparay area of Bandung. Based on OSS data, Ciparay has an LTE-A network penetration of $90 \%$, this shows that the traffic in the area is very dense. In addition, the value of LTE-A network throughput in this area is only $6.8 \mathrm{Mbps}$. This still does not meet operator standards where throughput is> $16 \mathrm{Mbps}$. To overcome this, optimization of frequency usage and increase in throughput are carried out using the Carrier Aggregation Deployment Scenario 2 (CADS2) method by combining two carrier components on a $15 \mathrm{MHz}$ bandwidth in band 3 (1800 $\mathrm{MHz})$ and bandwidth 20 in band $40(2300 \mathrm{MHz})$. In scenario I, band 3 is set as a primary cell and band 40 is set as a secondary cell, whereas in scenario II, band 40 is set as a primay cell and band 3 is set as a secondary cell. The results obtained are an increase in average throughput of $94,87 \%$.
\end{abstract}

Keywords: LTE-A, OSS operator, CADS2, throughput, Ciparay Bandung 


\section{PENDAHULUAN}

Berdasarkan hasil identifikasi data trafik dari operator, diperoleh data bahwa trafik di area Ciparay yang berada di Kabupaten Bandung memiliki nilai throughputyang rendah. Salah satu penyebab hal tersebut adalah karena area ini merupakan kawasan padat pemukiman serta adanya pusat keramaian seperti pasar tradisional dan alun-alun. Selain itu, data juga menunjukkan rata-rata penetrasi jaringan LTE-A telah menyentuh angka $90 \%$. Serta payload dari jaringan LTE-A telah menyentuh angka 243,5 Gigabyte dalam satu harinya dimana hal tersebut telah melebihi batas standar operator yaitu payload LTE-A sebesar 30 Gigabyte. Hal ini mengindikasikan bahwa kondisi trafik di area Ciparay sangat padat. Selain itu, rata-rata cakupan di area Ciparay masih jauh berada dibawah standar operator ditandai dengan jumlah rata-rata persentase parameter Reference Signal Received Power (RSRP) dengan nilai di atas $-100 \mathrm{dBm}$ hanya $52 \%$.

Teknologi LTE-Advanced adalah teknologi yang mampu memberikan kecepatan datarate hingga 3 Gbps pada sisi downlink dan 1,5 Gbps pada sisi uplink. Salah satu fitur yang menjadi faktor bertambahnya data rate tersebut adalah dengan adanya teknik Carrier Aggregation (CA). Hingga saat ini teknik ini terus diteliti dalam implementasinya di lapangan. CA merupakan sebuah metode penggabungan dua atau lebih Component Carrier (CC) dengan bandwidth maksimum $100 \mathrm{MHz}$ sehingga teknologi tersebut dapat memenuhi kebutuhan trafik layanan yang tinggi serta menghasilkan kecepatan datarate yang tinggi (Kurniawan, E. S., dkk, 2019). CA merupakan suatu teknik menggabungkan dua atau lebih Component Carrier (CC) secara bersamaan baik pada band frekuensi yang sama maupun berbeda dengan maksimum CC yang dapat dikumpulkan hingga $100 \mathrm{MHz}$ untuk meningkatkan data rate di sisi pelanggan. Salah satunya yaitu Carrier Aggregation Deployment Scenario (CADS2) dimana cell pada frekuensi 1 (F1) dan frekuensi 2 (F2) saling co-located dan overlay dengan F1 and F2 pada band frekuensi yang berbeda. F1 yang memiliki coverage yang luas, sedangkan F2 digunakan untuk meningkatkan throughput (Gujral, E. \& Jadon, 2016). Adanya fitur CA membuat penggunaan frekuensi yang dimiliki operator akan semakin optimal tanpa terhalang oleh band dan meningkatkan throughput di sisi pelanggan (Shen, Z., 2012) (Xi, 2013).

Dengan menggunakan skenario intra-band CA throughput dari CA yang tidak berdekatan memiliki kinerja yang lebih baik dibandingkan dengan CA yang berdekatan. Sebaliknya di CA intra-band skenario, kombinasi CC dengan frekuensi yang lebih rendah menghasilkan kinerja throughput yang lebih baik (Fadlan, I., 2017) (Iskandar \& Galih, 2015). Dari beberapa jenis CA, penelitian ini mengevaluasi konfigurasi CA terbaik pada parameter pengamatan yaitu throughput jaringan. Bandwidth aggregat $30 \mathrm{MHz}$ dan dua CC berfungsi sebagai PCell dan SCell digunakan dalam simulasi. Hasil simulasi menunjukkan bahwa konfigurasi bandwidth PCell yang lebih luas menghasilkan kinerja yang lebih baik.

Dalam implementasi jaringan nyata tidak diketahui mana yang memiliki kinerja terbaik, di antara CA Intra-band contigous, Intra-band non contigous, dan Inter-band, misalnya kinerja throughput pengguna. Tidak banyak publikasi penelitian yang mengungkapkan hal terkait dengan kinerja throughput CA. Salah satu diantaranya yaitu diusulkan dalam (Kakishima, Y., 2011), makalah ini membahas eksperimen lapangan hasil pada tingkat kesalahan blok (BLER) dari kontrol uplink informasi (UCI) dan kinerja throughput downlink dengan metode CA. Bandwidth adalah asimetris antara downlink dan uplink dengan frekuensi tengah yaitu 3,92625 $\mathrm{GHz}$ dan 3,67125 GHz. Dari penelitian ini diperoleh nilai throughput lebih dari $100 \mathrm{Mbps}$. Namun demikian, frekuensi operasi, bandwidth antara uplink dan downlink, serta kombinasi CC dari CA mungkin tidak akan sama dalam kasus lain. Area layanan, nomor site, frekuensi operasi, bandiwdth, dan jumlah pengguna mempengaruhi proses optimasi ini dan hasilnya. 
Dengan adanya data-data ini akan menjadi salah satu kontribusi dalam peningkatan throughput di area Ciparay.

CA merupakan suatu teknik menggabungkan dua atau lebih component carrier secara bersamaan baik pada band frekuensi yang sama maupun pada band frekuensi yamg berbeda dengan maksimum CC yang dapat digabungkan hingga $100 \mathrm{MHz}$ untuk meningkatkan throughput di sisi pelanggan (Saputra, D. W., dkk, 2015) (Technology, 2011). Pada artikel ini dilakukan optimalisasi penggunaan frekuensi LTE-A dengan metode dualbandCADS2 menggunakan tipe Inter-band carrier aggregation yaitu dengan mengumpulkan dua CC pada dua buah band frekuensi yang berbeda dimana menggabungkan dua buah component carrier pada bandwidth $15 \mathrm{MHz}$ di band $3(1800 \mathrm{MHz})$ dan bandwidth 20 di band $40(2300 \mathrm{MHz})$.

\section{METODOLOGI PENELITIAN}

Pada penelitian kali ini dilakukan perencanaan jaringan LTE-A dengan menerapkan dual band CADS2 tipe inter-band CA menggunakan band 3 sebesar $15 \mathrm{MHz}$ dan band 40 sebesar $20 \mathrm{MHz}$. Alasan pemilihan band ini adalah penambahan bandwidth yang lebih lebar dibandingkan band lain yaitu 1,4 MHz, $3 \mathrm{MHz}, 5 \mathrm{MHz}$ dan $10 \mathrm{Mhz}$ (Sesia, S., dkk, 2012). Proses perencanaan dimulai dengan melalui pendekatan capacity planning. Tahap ini meliputi perencanaan LTE-A untuk memperoleh nilai network throughput, cell average throughput, dan jumlah site. Setelah itu dilakukan perhitungan jarak jangkau dari frekuensi band 3 dan frekuensi band 40 . Untuk penggunaan frekuensi $2300 \mathrm{MHz}$ dengan bandwidth $20 \mathrm{MHz}$ akan dijadikan Primary Cell (Pcell). Untuk penggunaan frekuensi $1800 \mathrm{MHz}$ dengan bandwidth $15 \mathrm{MHz}$ akan dijadikan Secondary Cell (Scell). Penggunaan frekuensi $1800 \mathrm{MHz}$ dengan bandwidth $15 \mathrm{MHz}$ dijadikan Pcell dan frekuensi $2300 \mathrm{MHz}$ dengan bandwidth $20 \mathrm{MHz}$ dijadikan Scell pada simulasi menggunakan software Atoll pada CA terdapat berbagai potensi skenario yang dapat digunakan.

CA memungkinkan pemilihan band secara fleksibel guna meningkatkan coverage dan mobility. Gambar 1 berikut ini merupakan ilustrasi pemilihan band dengan menerapkan metode CA.

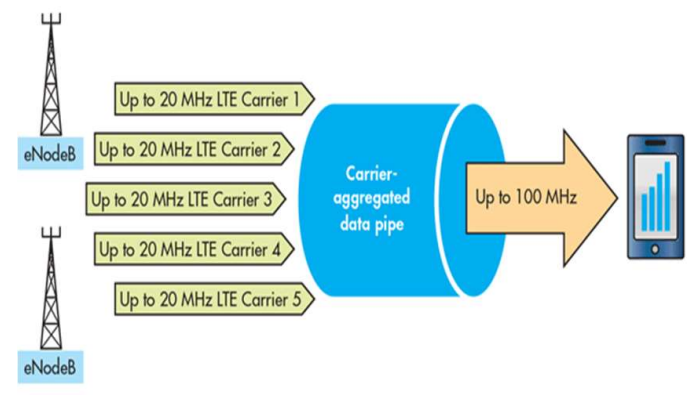

\section{Gambar 1. Ilustrasi Metode Carrier Aggregation (Iskandar \& Galih, 2015)}

Sel dengan carrier frequency F1 dan F2 letaknya co-located dan saling tumpang tindih. Namun pada skenario CADS2 ini sel dengan carrier frequency F2 memiliki cakupan yang lebih kecil sehingga meningkatkan laju data dan throughput. Sedangkan sel dengan carrier frequency $\mathrm{F} 1$ memiliki cakupan yang lebih luas untuk mendukung mobilitas. Biasanya skenario ini diterapkan ketika F1 dan F2 pada band frekuensi (Cox, 2012). 
Gambar 2 merupakan ilustrasi dari skenario CADS2.

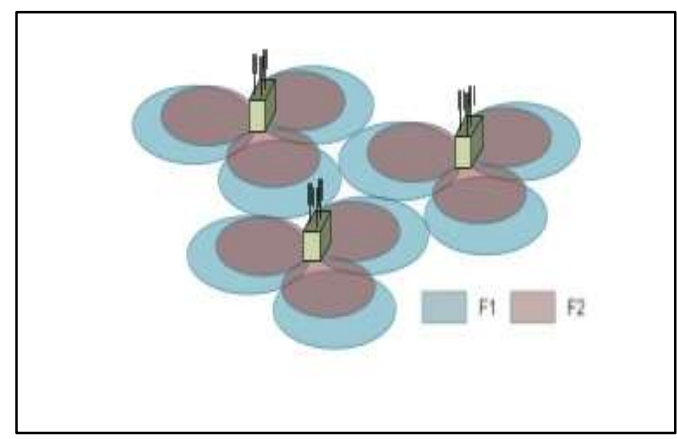

Gambar 2. Ilustrasi CADS2 (Cox, 2012)

\subsection{Identifikasi Area}

Dalam melakukan perencanaan jaringan seluler hal yang perlu diperhatikan adalah analisis area. Karena setiap area memiliki karakteristik yang berbeda-beda, seperti kontur bumi, kepadatan penduduk, dan kepadatan bangunan. Hal tersebut mempengaruhi sebaran kualitas sinyal pada suatu tempat, sehingga dilakukan analisis area untuk mengoptimalkan perencanaan jaringan LTE-A. Untuk perencanaan jaringan LTE-A dengan menggunakan dualband CADS2 dipilih daerah Kecamatan Ciparay Kabupaten Bandung. Gambar 3 merupakan orientasi Kecamatan Ciparay. Kecamatan Ciparay terbagi ke dalam 14 (empat belas) desa dengan jumlah penduduk 173.594 jiwa dan luas wilayah 48.36 km².

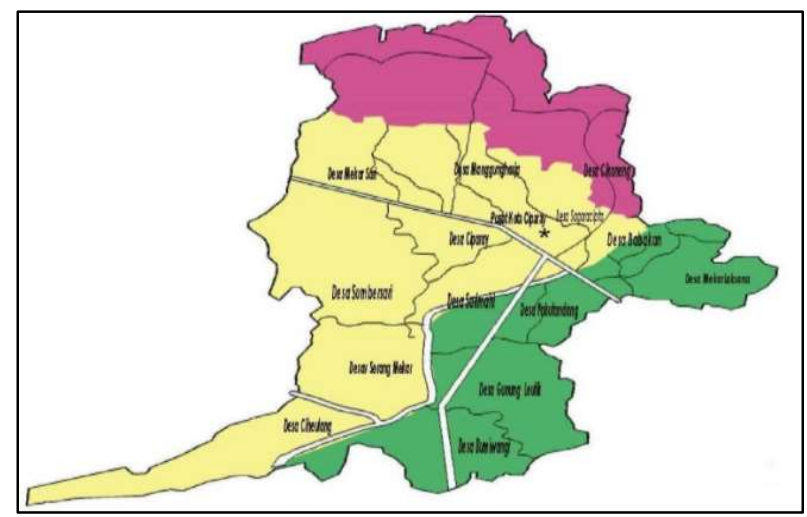

Gambar 3. Peta Area Ciparay (BPS, 2019)

\subsection{Identifikasi Operating Support System (OSS)}

Gambar 4 berikut merupakan grafik dari data trafik operator yang menampilkan nilai throughput pada salah satu site yaitu BDG112ML1_PSRCIPARAY di Kecamatan Ciparay. Data diambil pada rentang 22 November hingga 26 Desember 2019, diketahui nilai throughput yaitu 6,8 Mbps. Sedangkan operator memiliki nilai standar throughput $>16 \mathrm{Mbps}$, hal ini menunjukkan bahwa kondisi ini perlu diperbaiki. 


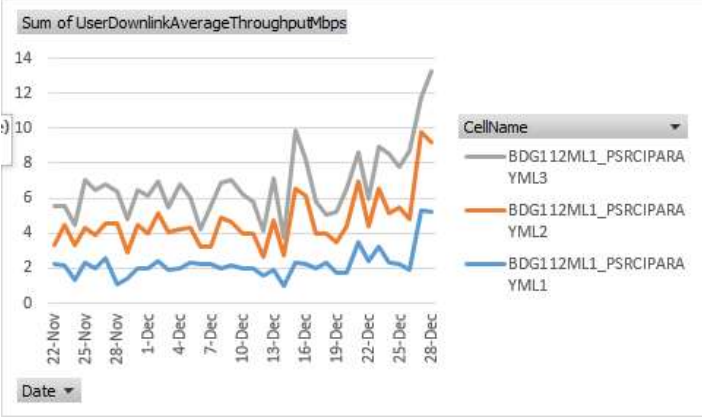

Gambar 4. Data OSS Throughput

Selain evaluasi terhadap data trafik, dari hasil identifikasi area ini juga diketahui bahwa Operator Tsel pada masing-masing site-nya telah dipasang antena yang berada pada rentang frekuensi $1800 \mathrm{MHz}$ hingga $2300 \mathrm{MHz}$. Selain diketahui bahwa tingginya trafik dan rendahnya throughput di area tersebut, jika dibandingkan dengan membangun towerbaru atau new site, maka jauh lebih efektif dan efisien jika dilakukan optimasi dengan penambahan port untuk antena baru.

\subsection{Perencanaan Jaringan menggunakan Metode CADS2}

Pada tahap ini dijelaskan proses perencanaan jaringan LTE-A menggunakan dualband CADS2 dengan tipe inter-band CA menggunakan band 3 sebesar $15 \mathrm{MHz}$ dan band 40 sebesar 20 $\mathrm{MHz}$. Tabel 1 berikut ini merupakan spesifikasi perencanaan jaringan menggunakan CADS2.

Tabel 1. Spesifikasi Perencanaan

\begin{tabular}{|l|l|}
\hline \multicolumn{2}{|c|}{ Spesifikasi } \\
\hline Carrier Aggregation & Inter-band \\
\hline Klasifikasi Wilayah & Urban \\
\hline Frekuensi Band & $1800 \mathrm{MHz} \& 2300 \mathrm{MHz}$ \\
\hline Daya & $43 \mathrm{dBm}$ \\
\hline Tinggi Antena & $20 \mathrm{~m}$ \\
\hline Model Propagasi & Cost-231 \\
\hline
\end{tabular}

Proses perencanaan dimulai dengan melakukan pendekatan capacity planning. Tahap ini meliputi perencanaan LTE-A untuk menghasilkan nilai network throughput, cell average throughput, dan jumlah site. Setelah itu dilakukan perhitungan coverage planning untuk mengetahui jarak yang dapat dicakup dari frekuensi band 3 dan frekuensi band 40. Setelah melakukan pendekatan capacity dan coverage planning, selanjutnya adalah plotting site berdasarkan kondisi awal. Untuk penggunaan frekuensi $2300 \mathrm{MHz}$ dengan bandwidth $20 \mathrm{MHz}$ dijadikan PCell, untuk penggunaan frekuensi $1800 \mathrm{MHz}$ dengan bandwidth $15 \mathrm{MHz}$ dijadikan SCell (Huawei LTE RNP, 2010).

\subsection{Coverage Planning}

Coverage planning pada dasarnya bertujuan untuk mendapatkan jumlah site berdasarkan luas daerah dan luas site. Namun, pada penelitian ini perhitungan bertujuan untuk mengetahui radius cel/antara frekuensi $1800 \mathrm{MHz}$ dan $2300 \mathrm{MHz}$ sehingga dapat diketahui bahwa frekuensi tinggi memiliki cakupan yang lebih kecil sedangkan frekuensi rendah memiliki cakupan yang lebih besar (Cox, 2012) (Ltd, 2009a). Pada pendekatan ini dilakukan tiga perhitungan antara lain Maximum Allowable Pathloss (MAPL), radius sel, dan cell coverage. 
Perhitungan MAPL menggunakan (1).

$$
\begin{gathered}
\text { MAPL }=46,3+33,9(\log f)-13,82 \log h_{b}-a\left(h_{m}\right)+ \\
\left(44,9-6,55 \log h_{b}\right) \log d-\operatorname{Cm} a\left(h_{m}\right)
\end{gathered}
$$

Faktor koreksi antena mobile station untuk area Urban adalah (2):

$$
a(h m)=(1,1 \log f-0,7) h m-(1,56 \log f-0,8)
$$

Keterangan:

$\mathrm{f} \quad=$ frekuensi $(\mathrm{MHz})$

$\mathrm{h}_{\mathrm{b}} \quad=$ tinggi antena eNodeB $(\mathrm{m})$

$\mathrm{h}_{\mathrm{m}} \quad=$ tinggi antena MS (m)

$\mathrm{a}\left(\mathrm{h}_{\mathrm{m}}\right)$ = faktor koreksi antena mobile station $(\mathrm{m})$

$\mathrm{C}_{\mathrm{m}} \quad=$ faktor jenis-jenis daerah

$\mathrm{C}_{\mathrm{m}}$ untuk kota besar $\quad=3$

$\mathrm{C}_{\mathrm{m}}$ untuk kota medium $\quad=0$

$C_{m}$ untuk area suburban $\quad=-2\left(\log f(28)^{2}-5.4\right.$

$C_{m}$ untuk area rural $\quad=-4.78(\log (f))^{2}+18.33 \log (f)-40.94$

Langkah selanjutnya yaitu perhitungan radius sel menggunakan (3) dan (4).

$$
P_{L}=46,33+33,9 \log \left(h_{b}\right)-a\left(h_{m}\right)+\left[44,9-6,55 \log \left(h_{b}\right) \log d\right.
$$

$\mathrm{P}_{\mathrm{L}} \quad=$ Pathloss $(\mathrm{dB})$

$\mathrm{h}_{\mathrm{b}} \quad=$ tinggi eNode $\mathrm{B}(\mathrm{m})$

$\mathrm{a}\left(\mathrm{h}_{\mathrm{m}}\right)$ = faktor koreksi antena UE

$\mathrm{d}=\operatorname{radius}(\mathrm{km})$

$$
a\left(h_{m}\right) \text { urban }=(1,1 \log f-0,7) h_{m}-(1,56 \log f-0,8)
$$

$\mathrm{P}_{\mathrm{L}} \quad=$ Pathloss $(\mathrm{dB})$

$\mathrm{f} \quad=$ frekuensi $(\mathrm{MHz})$

$\mathrm{h}_{\mathrm{b}} \quad=$ tinggi eNode $\mathrm{B}(\mathrm{m})$

$\mathrm{h}_{\mathrm{m}} \quad=$ tinggi UE $(\mathrm{m})$

$\mathrm{d}=\operatorname{radius}(\mathrm{km})$

$\mathrm{a}\left(\mathrm{h}_{\mathrm{m}}\right)$ urban= faktor koreksi antena UE untuk area urban

Setelah mendapatkan radius sel, selanjutnya dilakukan perhitungan cell coverage untuk sektorisasi trisectoral menggunakan (5).

$$
\text { Luas cakupan sel }=1,95 \times d^{2}
$$

Dari perhitungan tersebut diperoleh bahwa luas cakupan sel untuk frekuensi $1800 \mathrm{MHz}$ adalah $1,528 \mathrm{~km}^{2}$ dan untuk frekuensi $2300 \mathrm{MHz}$ adalah $0,606 \mathrm{~km}^{2}$. 
Hasil perhitungan melalui pendekatan coverage planning ini dapat dilihat pada Tabel 2 berikut.

Tabel 2. Hasil Perhitungan Coverage Planning

\begin{tabular}{|c|c|c|c|c|}
\hline Parameter & Variabel & Unit & \multicolumn{2}{|c|}{ Nilai } \\
\hline Frekuensi & $\mathrm{f}$ & $\mathrm{MHz}$ & 1800 & 2300 \\
\hline Tinggi antena BS & $\mathrm{h}_{\mathrm{b}}$ & $\mathrm{m}$ & 20 & 20 \\
\hline Tinggi antena MS & $\mathrm{h}_{\mathrm{m}}$ & $\mathrm{m}$ & 1,5 & 1,5 \\
\hline MAPL (DL) & $\mathrm{PL}$ & $\mathrm{dB}$ & 136,706 & 133,0172 \\
\hline Faktor koreksi daya & $\mathrm{C}$ & $\mathrm{dB}$ & 0 & 0 \\
\hline Radius sel & $\mathrm{d}$ & $\mathrm{km}$ & 0,885 & 0,557 \\
\hline Luas cakupan sel & Cell coverage & $\mathrm{km}^{2}$ & 1,528 & 0,606 \\
\hline
\end{tabular}

\subsection{Capacity Planning}

Capacity planning adalah metode yang digunakan dalam perencanaan jaringan seluler yang mempertimbangkan kebutuhan trafik pelanggan di suatu daerah untuk masa yang akan datang. Kebutuhan trafik yang dihitung mengacu pada berbagai macam layanan yang diperkirakan akan digunakan oleh user. Sebelum dilakukan perhitungan kebutuhan trafik yang ada, perlu dilakukan estimasi jumlah total penduduk atau pelanggan yang ada dalam beberapa tahun kedepan. Sehingga kapasitas dari trafik yang ada dalam jaringan mampu untuk memenuhi kebutuhan trafik tiap pelanggannya. Perhitungan berdasarkan pendekatan capacity planning ini dilakukan untuk memperoleh jumlah site yang dapat menggunakan CA berdasarkan jumlah pengguna yang berada di wilayah perencanaan (Ltd, 2009b).

Perhitungan forecasting number of users dilakukan dengan menggunakan Persamaan (6) .

$$
\text { Future population }=P_{0}[(1+G F)] n
$$

Keterangan:

$$
\begin{array}{ll}
\mathrm{P}_{0} & =\text { Current population } \\
\mathrm{GF} & =\text { Grow factor } \\
\mathrm{N} & =\text { Number of forecasting years }
\end{array}
$$

Single User Throughput (SUT) merupakan perhitungan yang digunakan untuk memastikan throughput maksimum yang diterima oleh pengguna. Untuk mengetahui nilai SUT dilakukan perhitungan menggunakan Persamaan (7).

$$
\begin{gathered}
\left(\left[\sum(\text { Throughput } / \text { Session }) \times \text { BHSA } \times \text { Penetration Ratio } \times(1+\right.\right. \\
\text { Peak to average ratio })]) / 3600
\end{gathered}
$$

Keterangan:

BHSA (h) $\quad=$ Busy Hour Service Attempt

Penetration ratio $\quad=$ How good services can affect costumers

Langkah selanjutnya dilakukan perhitungan kebutuhan trafik pada jaringan atau network throughput menggunakan Persamaan (8) dan (9) berikut.

$$
\text { Network Throughput }(\text { Uplink })=\text { Total user } x \text { SUTuplink }
$$


Network Throughput (Downlink) $=$ Total user $x$ SUTdownlink Untuk memperoleh nilai site capacity menggunakan Persamaan (10) dan (11) berikut.

$$
\begin{aligned}
\text { Site Capacity }(\text { Downlink }) & =\text { Cell average throughput downlink } \times 3 \\
\text { Site Capacity }(\text { Uplink }) & =\text { Cell average throughput uplink } \times 3
\end{aligned}
$$

Pada saat perencanaan, banyaknya jumlah site yang dibutuhkan pada suatu daerah perencanaan harus diketahui. Jumlah site diperoleh dengan menggunakan Persamaan (12).

$$
\text { Number of Site }=(\text { Network Throughput }) /(\text { Site Capacity })
$$

Jumlah site yang dibutuhkan dalam perencanaan ini adalah 1 site untuk arah uplink dan 3 site untuk arah downlink. Hasil perhitungan berdasarkan pendekatan Capacity Planning ini ditunjukkan pada Tabel 3 berikut.

Tabel 3. Hasil Perhitungan Capacity Planning

\begin{tabular}{|c|c|c|c|}
\hline Parameter & Unit & Nilai (UL) & Nilai (DL) \\
\hline Perkiraan jumlah penduduk & Jiwa & \multicolumn{2}{|c|}{17243} \\
\hline Single user throughput & Kbps & 9,872 & 37,271 \\
\hline Network throughput & Mbps & 173,602 & 655,429 \\
\hline Site capacity & Mbps & 366,236 & 305,197 \\
\hline Jumlah site & Site & $0,474 \sim 1$ & $2,147 \sim 3$ \\
\hline
\end{tabular}

\section{HASIL DAN PEMBAHASAN}

\subsection{Konfigurasi CA}

Simulasi yang dilakukan terbagi menjadi dua skenario, dimana konfigurasi CA menggunakan kombinasi bandwidth yang dimiliki operator Tsel. Skenario I yaitu berdasarkan kondisi awal jaringan di Ciparay yaitu intra-band CA: Band $40(2300 \mathrm{MHz})$ dengan bandwidth $20 \mathrm{MHz}$. Skenario II yaitu dengan konfigurasi sesuai dengan Aggregated Transmission Bandwidth Configuration (ATBC): Band 3 (1800 MHz) dengan bandwidth $15 \mathrm{MHz}$. Konfigurasi pertama yaitu CA_3A-40A dan konfigurasi kedua yaitu CA_40A-3A.

\section{Tabel 4. Konfigurasi CA}

\begin{tabular}{|c|c|c|c|}
\hline Tipe CA \& Duplex & $\begin{array}{c}\text { CA } \\
\text { Configuration }\end{array}$ & $\begin{array}{c}\text { Aggregated Bandwidth } \\
(\mathbf{M H z})\end{array}$ & Max Number of CC \\
\hline Inter-band FDD-TDD & CA_3A-40A & 35 & 2 \\
\hline Inter-band TDD-FDD & CA_40A-3A & 35 & 2 \\
\hline
\end{tabular}

Pada Tabel 4 di atas, menunjukkan dua konfigurasi CA yang terbagi dalam 2 skenario pada saat proses simulasi. Skenario I yaitu kondisi awal jaringan atau intra-band CA. Skenario II yaitu menggunakan dua konfigurasi, konfigurasi pertama CA_3A-40A dan CA_40A-3A. Pada konfigurasi pertama frekuensi band 3 dijadikan sebagai Primary Component Carrier(PCC) dan band 40 sebagai Secondary Component Carrier(SCC).

CC dari CA_3A memiliki satu carrier dengan total Number of Resource Block (NRB) $<100$ Resource Block (RB) sehingga termasuk ke dalam bandwidth class A karena memiliki jumlah 75 RB dari penggunaan bandwidth $15 \mathrm{MHz}$. CC dari CA_40A memiliki satu carrier dengan total 
NRB $<100$ sehingga termasuk ke dalam bandwidth class A karena memiliki jumlah 100 RB dari penggunaan bandwidth $20 \mathrm{MHz}$.

Hasil simulasi kemudian dibandingkan dengan memperhatikan parameter throughput berdasarkan standar Operator Tsel. Perbandingan dilakukan untuk simulasi existing site, skenario I, dan skenario II.

\subsection{Konfigurasi CA_3A-40A}

Gambar 5 dan 6 berikut ini menunjukkan hasil simulasi cakupan untuk throughput konfigurasi CA_3A-40A yang diterima oleh user pada area pengamatan.

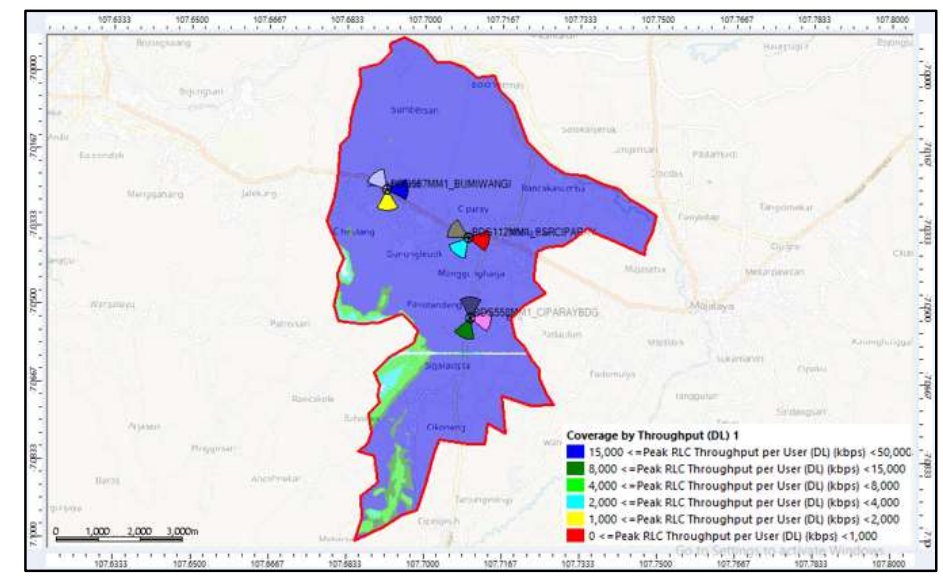

Gambar 5. Throughput Konfigurasi CA_3A-40A

Hasil simulasi menunjukkan bahwa nilai rata-rata throughput yang didapatkan adalah 23,4 Mbps.

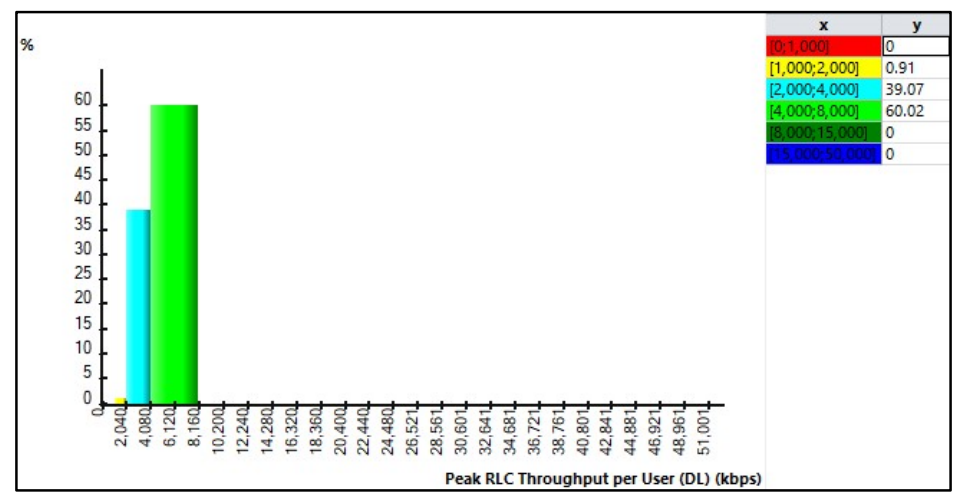

Gambar 6. Histogram Throughput Konfigurasi CA_3A-40A

\subsection{Konfigurasi CA_40A-3A}

Gambar 7 dan 8 berikut ini menunjukkan hasil simulasi cakupan untuk throughput konfigurasi CA_40A-3A yang diterima oleh user pada area pengamatan. 


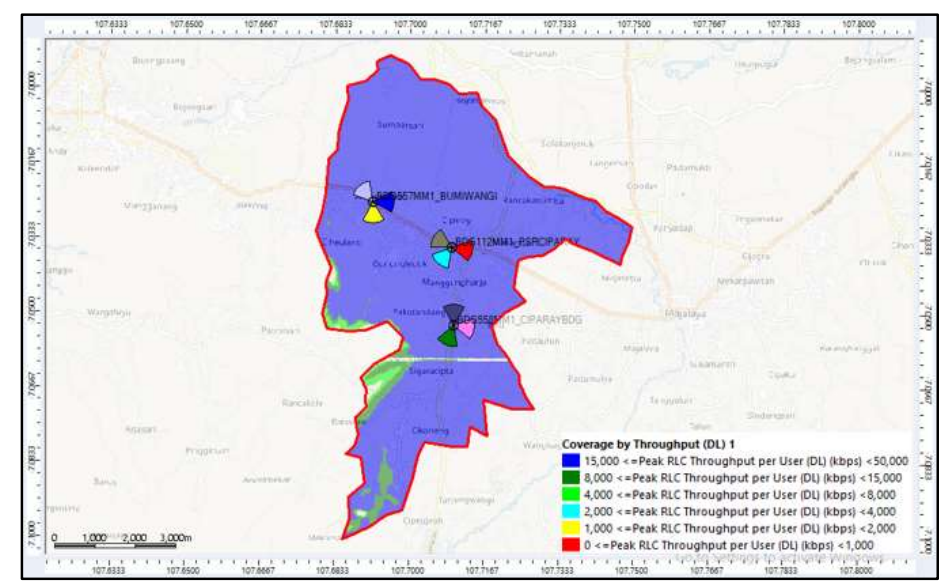

Gambar 7. Throughput Konfigurasi CA_40A-3A

Hasil simulasi menunjukan bahwa nilai rata-rata throughput yang didapatkan adalah 26,1 Mbps.

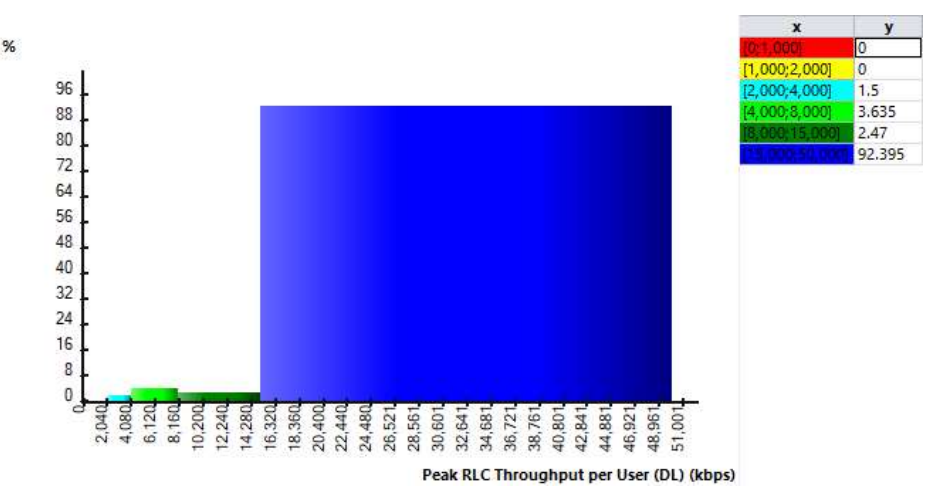

Gambar 8. Histogram Throughput Konfigurasi CA_40A-3A

Tabel 5 berikut merupakan perbandingan nilai parameter throughput untuk masing-masing skenario.

Tabel 5. Hasil Perbandingan Parameter Throughput

\begin{tabular}{|c|c|c|c|c|c|}
\hline Nilai (kbps) & Kategori & Warna & $\begin{array}{c}\text { Kondisi } \\
\text { Awal }\end{array}$ & $\begin{array}{c}\text { Skenario I: } \\
\text { CA_3A-40A }\end{array}$ & $\begin{array}{c}\text { Skenario II: } \\
\text { CA_40A-3A }\end{array}$ \\
\hline 15000 hingga 50000 & Outstanding & & $0 \%$ & $92,40 \%$ & $95,1 \%$ \\
\hline 8000 hingga 15000 & Excellent & & $0 \%$ & $2,47 \%$ & $3,44 \%$ \\
\hline 4000 hingga 8000 & Good & & $60,02 \%$ & $3,64 \%$ & $1,53 \%$ \\
\hline 2000 hingga 4000 & Fair & & $39,07 \%$ & $1,5 \%$ & $0 \%$ \\
\hline 1000 hingga 2000 & Poor & & $0,91 \%$ & $0 \%$ & $0 \%$ \\
\hline 0 hingga 1000 & Bad & & $0 \%$ & $0 \%$ & $0 \%$ \\
\hline \multicolumn{2}{|c|}{ Rata-rata } & 4,889 Mbps & $23,456 \mathrm{Mbps}$ & $26,161 \mathrm{Mbps}$ \\
\hline
\end{tabular}

Dari Tabel 5 dapat diketahui bahwa penerapan skenario II memperoleh nilai throughput yang lebih tinggi dibandingkan skenario I. Hal ini disebabkan karena pada skenario II dilakukan penggabungan dua buah frekuensi pada band frekuensi yang berbeda. Dimana frekuensi 1800 
$\mathrm{MHz}$ memberikan cakupan yang lebih baik, sedangkan frekuensi $2300 \mathrm{MHz}$ digunakan untuk meningkatkan throughput.

\section{KESIMPULAN}

Berdasarkan hasil simulasi CADS2 pada penggunaan CA dengan bandwidth $15 \mathrm{MHz}$ band 3 (1800 MHz) dan bandwidth $20 \mathrm{MHz}$ band $40(2300 \mathrm{MHz})$ untuk konfigurasi CA_3A-40A didapatkan nilai rata-rata throughput 23,456 Mbps, sedangkan konfigurasi CA_40A-3A didapatkan nilai rata-rata throughput 26,161 Mbps. Dari kedua skenario simulasi yang telah dilakukan diketahui bahwa inter-band CA mampu meningkatkan throughput dibandingkan dengan simulasi kondisi awal jaringan, dengan presentasi kenaikan throughput sebesar $94,87 \%$.

\section{UCAPAN TERIMA KASIH}

Terimakasih kepada pihak operator Tsel yang telah mendampingi dalam pengamatan OSS dan membantu dalam menganalisis kondisi trafik user di area Ciparay Bandung. Data ini sangat berarti dalam penyelesaian penelitian ini.

\section{DAFTAR RUJUKAN}

BPS. (2019). Badan Pusat Statistik Provinsi Jawa Barat.

Cox, C. (2012). An Introduction to LTE. John Wiley \& Sons, Ltd.

Fadlan, I., \& T. J. (2017). Performance Analysis of Inter-band and Intra-band Carrier Aggregation on Planning and Dimensioning LTE-Advanced in Bandung City. The 3rd International Conference on Wireless and Telematics 2017, (pp. 129-133).

Gujral, E., \& Jadon, J. S. (2016). LTE Evolution towards Carrier Aggregation (LTE-advanced). Journal of Telecommunications System \& Management, 5(1).

Huawei LTE RNP. (2010). LTE KPI Drive Test Guide and Measure method.

Iskandar, \& Galih, R. (2015). Throughput Evaluation in LTE-Advanced Network Access Using Carrier Aggregation. 1st International Conference on Wireless and Telematics (ICWT), (pp. 1-5).

Kakishima, Y., D. (2011). Experimental Evaluation on Throughput Performance of Asymmetric Carrier Aggregation in LTE-Advanced. Proceeding of IEEE 73rd Vehicular Technology Conference (VTC Spring), (pp. 1-5).

Kurniawan, E. S., Wahyudin, A., \& Danisya, A. R. (2019). Analisis Perbandingan LTE-Advanced Carrier Aggregation Deployment Scenario 2 dan 5 di Semarang Tenga. TECHNO, 20(2), 77-86.

Ltd, C. H. T. (2009a). LTE Link Budget Intoduction. In Huawei Confidential (pp. 3-17).

Ltd, C. H. T. (2009). LTE Radio Network Planning Introduction. In Huawei Confidential (pp. 
14-20).

Saputra, D. W., Usman, U. K., \& Meylani, L. (2015). Planning LTE-Advanced Using Carrier Aggregation Intra-Band Non-Contiguous and Inter-Band Non-Contiguous Method. IEEE Asia Pacific Conference on Wireless and Mobile, (pp. 36-40).

Sesia, S., Toufik, I.,\& Baker, M. (2012). LTE - The UMTS Long Term Evolution From Theory to Practice. John Wiley \& Sons, Ltd.,.

Shen, Z., D. (2012). Overview of 3GPP LTE-Advanced Carrier Aggregation for 4G Wireless Communications. IEEE Communications Magazine, 122-130.

Technology, H. (2011). Long Term Evolution (LTE) Radio Access Network Planning Guide.

Xi, C. (2013). Analysis of the Impact of TD-LTE on Mobile Broadband. 